This is the author's final, peer-reviewed manuscript as accepted for publication. The publisher-formatted version may be available through the publisher's web site or your institution's library.

\title{
Efficacy of purchasing activities and strategic involvement: an international comparison
}

Chen-Lung Yang, Ru-Jen Lin, Dennis Krumwiede, Elizabeth Stickel, Chwen Sheu

\section{How to cite this manuscript}

If you make reference to this version of the manuscript, use the following information:

Yang, C.-L., Lin, R.-J., Krumweide, D., Stickel, E., \& Sheu, C. (2013). Efficacy of purchasing activities and strategic involvement: An international comparison. Retrieved from http://krex.ksu.edu

\section{Published Version Information}

Citation: Yang, C.-L., Lin, R.-J., Krumweide, D., Stickel, E., \& Sheu, C. (2013). Efficacy of purchasing activities and strategic involvement: An international comparison. International Journal of Operations \& Production Management, 33(1), 49-68.

Copyright: () Emerald Group Publishing Limited

Digital Object Identifier (DOI): doi:10.1108/01443571311288048

Publisher's Link:

http://www.emeraldinsight.com/journals.htm?articleid=17072855\&show=abstract

This item was retrieved from the K-State Research Exchange (K-REx), the institutional repository of Kansas State University. K-REx is available at http://krex.ksu.edu 


\title{
Efficacy of Purchasing Activities and Strategic Involvement: An International Comparison
}

\author{
Chen-Lung Yang* \\ Department of Technology Management \\ Chung-Hua University, Taiwan \\ clyang@chu.edu.tw \\ Ru-Jen Lin \\ Department of Industrial Management \\ Lung-Hwa University of Science and Technology, Taiwan \\ rjlin@mail.lhu.edu.tw \\ Dennis Krumwiede \\ College of Business \\ Idaho State University, USA \\ krumdenn@cob.isu.edu \\ Elizabeth Stickel \\ College of Business \\ Idaho State University, USA \\ sticeliz@isu.edu \\ Chwen Sheu \\ Department of Management \\ Kansas State University, USA \\ csheu@ksu.edu
}

* Corresponding author 


\title{
Efficacy of Purchasing Activities and Strategic Involvement: An International Comparison
}

\begin{abstract}
The purchasing function plays a strategic role in a company's ability to compete. As globalization continues to increase, what becomes interesting is the effect that national culture may have on purchasing activities and, ultimately, manufacturing competitiveness. This study examines the effects of purchasing activities and the purchasing function's involvement with corporate strategy on manufacturing competitiveness as it is affected by national differences. In particular, we are interested in the research question: Do purchasing theories built on samples from mainly North American and Western European countries apply in other countries with different cultural contexts? The statistical results provide evidence that the engagement and efficacy of purchasing activities and strategic involvement within companies vary by national culture. Moreover, a particular cultural dimension, Longterm orientation, is significantly related to the efficacy of purchasing activities and strategic involvement. This finding has important implications from the perspective of purchasing decision-making in global operations. Specifically, top managers from different nations could adopt and implement similar purchasing activities, but those activities could lead to different outcomes depending on the culture. The paper concludes by reviewing research limitations and suggests further examination of operations management theories.
\end{abstract}

Keywords: Global operations management, Purchasing, Supply chain, National difference, GMRG, National culture

\section{Introduction}

Over the last two decades, the role of the purchasing function has been well recognized as a central component of the operations strategy of a company (Das and Narasimhan 2000; Krause et al., 2001; Narasimhan and Das 2001; Prahinski and Benton 2004; Rozemeijer et al., 2003; Talluri and Sarkis 2002). What is missing from the literature, however, is a thorough understanding of effects that national influence may have on purchasing activities and how this affects manufacturing performance. Despite cautions from many studies, the extant operations management (OM) literature often assumes that theories developed based on USA or European data are universal and, though with no empirical support, applicable to other countries (Flynn and Saladin, 2006; Meyer, 2007; Pagell et al., 2005, Kristal et al., 2011; Niehoff et al., 2011; Qing et al., 2011). From the perspectives of both research and industry practice, ignorance of national differences can be misleading. For instance, Hofstede 
(2007) found that many applications of management theory have failed even with the most experienced international companies due to cultural misunderstanding. In support of this, using Chinese samples, Zhao et al. (2006) found that a manufacturing strategy theory developed using North American data may not be applicable to Chinese firms.

The effects of national differences on purchasing activities are noted but not properly studied or validated (Krause et al., 2001; Quintens et al., 2006; Riedel and Mueller, 2009; Kristal et al., 2011). Often, purchasing studies have examined the issue of national differences using very limited data that were collected from a single country or two countries for comparison (Belyea, 2008; Pagell et al., 2005). Moreover, national difference is often treated as a control variable, while its explanatory influence on purchasing activities is not well understood. Yet it is vital that managers responsible for global operations understand how resident managers, based in different countries, make different decisions affecting purchasing activities (Belyea, 2008; Riedel and Mueller, 2009). The overarching objectives of this study are, therefore, to validate previous findings showing cultural differences in purchasing activities and to further the understanding of how national differences influence the efficacy of purchasing activities on manufacturing performance.

The particular research question we intend to address is whether purchasing theories, though well grounded in the literature, are, in fact, universal and applicable to countries with distinct cultures. Specifically, we investigate the relationship between purchasing activities (including the implementation of purchasing activities and strategic involvement of purchasing functions) and manufacturing competitiveness performance across two culturally distinct country groups, Western Europe/USA and Asia. The following section reviews relevant literature pertaining to several frequently cited purchasing activities and strategic purchasing involvement and their importance to manufacturing performance. Research hypotheses are developed, followed by the presentation of research methodology, including 
samples and measurements. The statistical results and discussion in relation to national differences are presented. Finally, managerial implications and suggestions for future research are provided.

\section{Literature Review \& Theoretical Development}

Based on the purchasing literature (see Carter et al., 2000; Das and Narasimhan, 2001; Krause et al., 2000; Narasimhan and Das, 2001; Ellram et al., 2002; Petersen et al., 2005) and suggestions from a group of experts (Whybark et al., 2009), this section selects and reviews several purchasing activities that are frequently discussed and implemented in the industry. This list of purchasing activities encompasses various practices related to procurement, supplier development and supplier involvement. For each purchasing activity, we review its impacts on various aspects of manufacturing performance, including cost, quality, delivery, and flexibility. We also review the effect of purchasing strategic involvement as suggested by previous studies (Lawson et al. 2009; Narasimhan and Das, 2001; Tan, 2002).

\subsection{Purchasing activities}

a. Buyer sponsored supplier conferences. Ellram and Edis (1996) described buyersponsored supplier conferences as meetings with the firm's suppliers that cover such issues as expectations for the suppliers, as well as issues relating to the long-term supplier-buyer relationship. The involvement and importance of buyer and seller collaboration is evident in the literature. Several studies cited supplier conferences as a critical activity that enhances supplier and buyer collaboration and manufacturing performance (Carr and Pearson, 1999; Carter et al., 2000; Chen et al., 2004).

b. Formal strategic sourcing process. Narasimhan and Das (2001) and Talluri and Narasimhan (2004) emphasized the importance of the strategic sourcing process that involves 
careful selection of suppliers, development of long-term relationships, and implementation of a continuous feedback system between buyer and supplier. The strategic sourcing process includes insourcing and outsourcing decisions, both of which contribute greatly to delivery performance (Carter et al., 2000; Sislain and Satir, 2000).

c. Reverse auctions. Reverse auctions allow buyers to make purchases by observing a series of bids from sellers (Essig and Arnold 2001; Shrader et al., 2004). Supply chain partners around the world can get connected using web-based electronic reverse auctions. Carter et al. (2000), Essig and Arnold (2001) and Rhea (2007) confirmed that e-procurement programs with e-reverse auctions could lower purchasing transaction costs, as well as increase opportunities for the purchasing function to produce value for the firm.

d. Supplier representatives in plant. McIvor and McHugh (2000) identified supplier representatives in plants as assisting in two areas - purchasing and new product introduction. Suppliers could become members of cross-functional teams within the organization with their added benefit dependent on their level of participation and fellow team members' willingness to work with the supplier representative (Narasimhan and Das, 2001). Womack and Jones (2003) suggested that having supplier representatives housed in manufacturing facilities helps to quickly reduce response time associated with problems and mitigates negative effects. Specifically, with regard to new product development, utilizing supplier representatives reduces risks and resources, increases knowledge and its sharing, and reduces product-tomarket time. Sara Lee Co. experienced a five-fold increase in process innovation with the use of in-plant supplier representatives who provided quicker and more accurate feedback on quality and innovation (Atkinson, 2006).

e. Strategic alliances/partnerships. A strategic alliance is a formal partnership between at least two firms that contributes to the strategic objectives of each firm (Pearson et al., 1998). Strategic supplier alliances and partnerships can become competitive advantages 
through the development of long-term mutually beneficial relationships (Chen et al., 2004; Kannan and Tan, 2002; Narasimhan and Das, 2001; Vonderembse and Tracey, 1999). In general, a long-term strategic relationship would allow for informal communication that can expand the involved companies' knowledge of competitive issues through greater discovery and disclosure of information.

f. Commercial procurement software (e-procurement). Electronic procurement, often thought of as web-based procurement, includes web-based enterprise resource planning (ERP), e-sourcing, e-tendering, e-reverse auctioning, and e-informing (Carter et al., 2000; Kinner and Marci, 2005). Benefits of e-procurement include greater quantity and quality of information, thereby reducing uncertainty in purchasing activities, as well as faster processing in procurement activities (Essig and Arnold, 2001).

g. Cross-functional commodity teams. According to Rozemeijer et al. (2003), crossfunctional commodity teams manage supply and purchasing requirements of many business units within a firm by utilizing collaboration from various functional units. Developing purchasing synergy is the primary goal of cross-functional teams. Ellram et al., (2002) and Ellram and Edis (1996) confirmed the contribution that purchasing teams make toward the overall cost performance of a firm. Sarin and McDermott (2003) also showed that crossfunctional teams allow for greater innovation and speed in decision making.

\section{h. Early supplier involvement in design/redesign of products. Ellram et al., (2002)} and Ellram and Edis (1996) considered early supplier involvement an effective communication mechanism during the beginning stages of product development and procurement operations. They suggested that early supplier involvement is important for new product development. Primo and Amundson (2002) also suggested there is a significant benefit to product quality from involving the vendor in new product development. Vendors who are intimately involved with companies in early design processes defining product 
requirements can significantly reduce cost and schedule performance issues by substantially reducing rework or total redesign of components involved with new designs. Kodak found many of these benefits in its early supplier involvement efforts with product design, as well as the benefits of reduced cycle time and quality problems (Ellram et al., 2002).

\section{i. Non-direct materials (MRO purchases) delegated to manufacturing/operations.}

Maintenance, repair, and operations (MRO) purchases are trending toward being outsourced, resulting in a reduced supplier base and potential cost savings (Tan, 2002). In a survey distributed to 400 Fortune 500 purchasing groups, $42 \%$ responded that their companies had undergone significant changes in their MRO purchasing procedures, resulting in delegation of these procedures to the internal users of the goods/services (Carter et al., 2000; Hendrick et al., 1996).

j. Supply base rationalization (decrease/increase base). Determining the appropriate number of suppliers is the main foundation for supply base rationalization. The extant literature suggests that supply base rationalization enforces effective supplier selection, volume consolidation, and parts bundling, which in turn contribute to cost reduction and quality improvement, as is the case with Rover Motors (Das and Narasimhan, 2000; Narasimhan and Das, 2001).

\section{k. Purchased items are classified as strategic or tactical and are purchased by}

separate teams. Tactical activities are considered to be of lower importance than other purchasing activities. These activities include several processes such as ordering, quoting, and expediting (Carter et al. 2000). Tactical purchases are likely to be outsourced and/or automated over the next ten years, with many tactical purchases pushed into large contracts, thereby reducing the number of employees involved in these purchases (Carter et al., 2000). In contrast, strategic purchases represent items of greater importance, with the procurement process focusing on supplier selection, and selection and development of cross-functional 
teams. Trent (2004) asserted that separation between strategic and tactical purchases improves procurement efficiency.

1. Formal supplier development program. Prahinski and Benton (2004) defined formal supplier development programs as efforts by purchasing firms to measure and improve service and/or products received from supplying firms. Such programs can contribute to increased supplier and purchaser performance through enhanced communication and knowledge, which results in a significant positive improvement in buyer-supplier relationship (Petersen et al. 2005). They also discovered that supplier development activities are positively and significantly related to all aspects of manufacturing performance.

\subsection{Purchasing strategic involvement}

Strategic involvement, viewed as the integration of the purchasing function into corporate strategy, has been recognized for its strategic role (Johnson et al., 1998; Lawson et al., 2009; Narasimhan and Das, 2001; Tan, 2002). Many have even argued that purchasing contributes significantly to corporate performance, and thus, supply chain management and should be a key component for consideration when developing a company's overall strategy. In support of this idea, Pearson et al. (1998) discussed how overall firm performance is influenced by strategic supplier activities, especially in an international setting, pointing to additional reasoning in support of incorporating the purchasing function into corporate strategy. Lawson et al. (2009) and Tan (2002) found that companies are increasingly incorporating purchasing activities into corporate strategy, and he suggested that more research should be conducted on the specifics of integrating the purchasing function into corporate strategy.

Based on the above literature review, a theoretical model is proposed in Figure 1. We posit that those purchasing activities and the strategic involvement of purchasing have positive impacts on manufacturing competitiveness measures of cost, quality, delivery, and flexibility. The following hypotheses are thus developed. 
H1: Purchasing activities (PA) contribute to manufacturing competitiveness (MC)

H2: Purchasing strategic involvement (SI) contributes to manufacturing competitiveness (MC)

\section{$<$ Insert Figure 1 here $>$}

The research hypotheses are developed in order to test a purchasing model that, though well-grounded in the literature, has never been examined with a large international dataset. The impact of national differences on the role and the practice of purchasing activities require further investigation (Carr et al., 2000; Kristal et al., 2011; Monczka et al., 2009). For instance, there is a greater awareness of the importance of resource utilization as influenced by the concept of lean manufacturing and just-in-time systems in Asia (Carr et al., 2000). Many Asian manufacturers in China, Korea, and Taiwan use outsourcing to obtain the best components at the lowest possible price. They contract with vendors who's margins are thin owing to intense competition. These manufacturers depend on suppliers that can deliver cost effective, quality parts and in a timely manner. As such, the role of purchasing has become an important strategic function with an emphasis on more effective cost control and supply chain management (Qing et al., 2011). The remainder of this section discusses the need for testing this model, taking into consideration national differences.

\subsection{National culture differences}

Global Studies in various management fields have been performed analyzing cultural effects, such as supply chain effectiveness, project management, forecasting, and regulation compliance on supply performance. For instance, Wacker and Sprague (1998) considered the role of national cultural differences and the underlying approach in forecasting. Pagell et al. (2005) found that national cultural differences significantly influence international operations management behaviors among similar manufacturing plants in the same industry located in different cultures. Flynn and Sladin (2006) examined whether or not the Baldrige criteria have relevance in countries with cultural differences. International projects raise additional 
issues and problems that have to be managed, such as legal/political issues, security, geography, economic status, infrastructure, and culture (Gray and Larson, 2006). Ruamshook et al. (2007) suggested that, to maintain and improve a firm's future competitive advantage under conditions of heightening global competition, firms must develop and enhance management knowledge in order to optimize the strategic values of differing regions and nations of supply. Their findings indicated the existence of country or regional differences pertaining to supplier performance in the supply chain.

Several researchers have used national culture to illustrate and explain differences between countries. Hofstede (1980) defined national culture as the collective mental programming of the people in a national context. Through an empirical study examining more than 10,000 managers in over 50 countries, he developed a quantitative classification scheme for measuring differences and similarities between national cultures. He then proposed that attitudes, beliefs, and behaviors could be categorized into five dimensions: individualism-collectivism, masculinity-femininity, power distance, uncertainty avoidance, and long-term orientation (Confucianism). In light of these five dimensions, Hofstede et al. (2002) stated that people of a nation have "patterns of thinking, feeling, and acting that differentiate one country from another and continue to be transferred from generation to generation." Table 1 provides definitions for the five dimensions and the respective indices for different regions. There seem to be significant cultural differences between Asian, USA, and Western European countries, especially regarding long-term orientation (LTO). Specifically, Asian countries receive an average score of 95, while both USA and Western Europe have average scores of 25 .

\section{<Insert Table 1 Here >}

According to Hofstede et al. (2002), Long-term orientation (LTO) (Confucianism) refers to the extent to which one has a long- or short-term orientation. Values associated with Long- 
term orientation are thrift and perseverance; values associated with Short-term orientation are respect for tradition, fulfilling social obligations, and protecting one's 'face'. LTO was previously discussed as an influential factor in purchasing activities. For instance, the strategic sourcing process involves planning and organizing long-term purchasing agreements with suppliers, as suggested by Cavinato et al. (2006). They argued that companies operating in cultures with higher future orientations would be more likely to utilize formal strategic sourcing processes. Moreover, Tucker (2008) asserted that strategic supplier partnerships allow for sharing of information that can be vital for the success of both organizations involved, especially when crossing international borders. The development and planning involved in these alliances and partnerships could be supported by a country's future orientation. Barnes (2008) suggested that supply base rationalization is supported by a future orientation, where organizations understand the ever-changing environment and make decisions to develop relationships and rationalize their supply base in an attempt to prepare for the future and secure success.

Overall, the extant literature has successfully demonstrated the effects national differences can have on various operations and supply chain decisions. Nonetheless, empirical support for the effect of national differences on purchasing activities is weak and is mostly from case studies or small-scale survey research, with only two-country comparisons (see example, Carr et al. 2000). The issue of national differences and purchasing activities has not yet been properly examined. This study intends to use a large-scale dataset, with samples from multiple countries to further understanding of this issue. In particular, this study adds to the literature by considering the role of national differences across ten countries involving 511 manufacturing plants. Based on the LTO scores, we combined three Asian countries (China, Korea, and Taiwan) into one group, while Australia, the USA, and several Western European countries (Austria, Germany, Italy, Switzerland, and Sweden) were 
combined into another group. Table 2 summarizes the issues of the two groups of countries. There is a glaring difference in LTO scores between the two groups. The average LTO score for the first group is 93.33, which is significantly higher than that of the second group, 33.29. We posited that national differences, from the long-term orientation standpoint, could potentially influence the choice and, thus, the efficacy of various purchasing activities and strategic involvement. Therefore, the following hypotheses are developed:

H3: There are significant national culture differences in the relationships among purchasing activities (PA), strategic involvement (SI), and manufacturing competitiveness (MC)

H3a. National culture differences affect the emphasis placed on purchasing activities (PA) and strategic involvement (SI)

H3b. National culture differences affect the contribution of purchasing activities (PA) and strategic involvement (SI) to manufacturing competitiveness (MC)

\section{<Insert Table 2 here >}

\section{Research Method}

\subsection{Data}

The data was a subsample of Round IV of the Global Manufacturing Research Group (GMRG) survey effort. The GMRG is a multinational community of researchers studying the improvement of manufacturing practices worldwide (www.gmrg.org), and consists of leading international academic researchers from over twenty countries who developed the GMRG database survey instrument for use around the world. This survey facilitates global comparison of the effectiveness of manufacturing practices (Whybark et al., 2009). Since 1985, the GMRG has completed four rounds of the worldwide survey, from the most recent of which we obtained our data. The questionnaires were translated and back-translated for all countries by several academics. This study used the 511 samples collected from ten countries to perform necessary analyses for testing the proposed research hypotheses and the purchasing model (Figure 1). More details of the samples can be found in Table 3. 


\section{$<$ Insert Table 3 Here $>$}

\subsection{Measurement: constructs of interest}

The items used in the analysis are presented in Appendix A. The purchasing activity (PA) scale addresses various activities in which purchasing personnel engage, including procurement, supplier involvement and development. For each purchasing activity, managers were asked to what extent the activity is implemented (on a scale of 1-7 with 1 being "not used" and 7 being "a great extent"). All the activities are selected from the following literature: Carter et al. (2000), Krause et al. (2000), Narasimhan and Das (2001), Ellram et al. (2002) and Petersen et al. (2005). Overall, a high score on this scale indicates the purchasing function is actively engaged in a large number of these purchasing practices, while a low score indicates a lower level of effectiveness or involvement. The scale for strategic involvement (SI) was adopted from Rozemeijer et al. (2003) and Lawson et al. (2009). It measures the levels at which the purchasing function participates in forming strategic plans and receiving support from top management. A low score suggests a low degree of strategic involvement from the purchasing function.

The scales for manufacturing competitiveness (MC) have respondents rate their competitiveness as compared to their major industry competitors (Kull and Wacker, 2010). We captured the four main dimensions of manufacturing competitiveness: cost, quality, flexibility, and delivery. The scale for continuous improvement was created and verified by previous GMRG studies (Pagell et al., 2005; Yang et al., 2010).

\subsection{Psychometric properties}

In this study, we used multiple items to present three latent constructs, Purchasing Activity (PA), Strategic Involvement (SI), and Manufacturing Competitiveness (MC). Each latent construct was tested for internal consistency using Cronbach's alpha and construct reliability. Table 4 shows that alpha coefficients were between 0.73 and 0.89 , which are above the 
benchmark of 0.70 suggested by Nunnally (1978), and construct reliabilities were between 0.74 and 0.87 , which are above 0.60 . Overall, the results suggest high internal consistency of measurement indicators and, hence, reliability of each construct is ensured.

\section{$<$ Insert Table 4 here $>$}

Next, convergent validity and discriminant validity were assessed. O'Leary-Kelly and Vokurka (1998) suggested that the use of CFA to assess convergent and discriminant validity is more powerful and requires fewer assumptions than the traditional MTMM (multi-trait multi-method) matrix method. In the CFA model, each item was linked to its corresponding construct and the covariances among those constructs were freely estimated. The resulting model fit indices are $\chi^{2}(237)=529.916, \mathrm{IFI}=.944, \mathrm{NFI}=.904, \mathrm{CFI}=.944, \mathrm{RMSEA}=.049$, which were better than the threshold values recommended by Hu and Bentler (1998). Moreover, all of the factor loadings are greater than 0.60 and the $t$-values are significantly greater than 2.0. In summary, the convergence of items on the factors they are intended to measure with significant positive loadings and a good overall model fit demonstrate the convergent validity and unidimensionality of these scales (Hair et al., 1998).

Discriminant validity is tested by comparing the correlation coefficients between latent constructs with the variance-extracted percentages for each construct (Fornell and Larcker, 1981). The results indicate the variance-extracted percentages for constructs were higher than the correlation coefficients between latent constructs. The variance inflation factors (VIF) of all latent constructs were below the recommended value of ten, implying the lack of multicollinearity, thus discriminate validity is supported.

\section{Statistical Analysis}

For the purposes of this study, two statistical methods were applied. First, multiple-group structural equation modeling (SEM) analysis was performed to test the postulated research hypotheses and the model in Figure 1. Next, we applied regression analysis to examine 
whether the two country groups differ in their choice and efficacy of purchasing activities and strategic involvement.

\subsection{SEM analysis}

A series of multi-group SEM analyses were performed, using LISREL 8.70, to examine whether different groups (Group 1: Asia; Group 2: Western Europe/USA) have different path coefficients of the structural model (Byrne, 1994). We also performed another analysis treating Asia, USA and Western Europe as three separate groups. Table 5 summarizes the SEM results; including model fit indices, standardized path coefficients, and significance levels. The results for both SEM analyses, two groups (Asia vs. Western Europe/USA) and three groups (Asia vs. Western Europe vs. USA), are similar. Our discussion is based on the findings from the two-group analysis as presented in Table 5a.

\section{<Insert Table 5 here $>$}

First, for the All-sample group, the fit indices were all found to be within an acceptable range $(\mathrm{CFI}=96, \mathrm{NFI}=.94, \mathrm{RMSEA}=.050)$, suggesting a good fit between the modelimplied covariance matrix and the data. All causal paths are statistically significant at the 0.05 level, supporting $\mathrm{H} 1$ and H2. In other words, both purchasing activities and strategic involvement improve all four aspects of manufacturing competitiveness where the impacts on delivery $\left(\lambda=4.30^{*} ; \lambda=4.47^{*}\right)$ and flexibility $\left(\lambda=4.09^{*} ; \lambda=4.43^{*}\right)$ are higher than on cost $(\lambda$ $\left.=1.77^{*} ; \lambda=2.04^{*}\right)$ and quality $\left(\lambda=2.04^{*} ; \lambda=2.24^{*}\right)$.

The results also suggest the moderating effects of national culture on the causal model since two groups display different path coefficients of the structure model (Byrne, 1994). As shown in Table 5a, three causal paths are moderated by the variable of culture (i.e., PA $\rightarrow$ Cost, PA $\rightarrow$ Quality; SI $\rightarrow$ Cost). According to the estimated path coefficients, the impact of purchasing activities on cost and quality for the Asia group is significantly different from that of the Western Europe/USA group $\left(\Delta \chi^{2}=42.52 * *(\operatorname{Cost}) ; \Delta \chi^{2}=21.62 *(\right.$ Quality $\left.)\right)$. 
Meanwhile, the effect of SI on Cost is also significantly different between the two groups $\left(\Delta \chi^{2}=50.56^{*}\right)$. The results suggest that the strategy of improving cost and quality performance by performing purchasing activities works effectively for the Western Europe and USA group but not so for the Asia group. On the other hand, the Asian samples appear to benefit more from purchasing strategic involvement than the Western Europe/USA samples regarding cost performance $\left(\lambda=1.64^{*}\right.$ vs. $\left.\lambda=1.09^{*}\right)$.

For the second SEM analysis (Asia vs. Western Europe vs. USA), similar results are found (Table 5b). Namely, the impact of purchasing activities on cost and quality for Group $\# 1$ are significantly different from Groups \#2 and \#3. In the meantime, the path coefficients for the USA group and the Western Europe group are not significantly different. While more studies must be performed to generalize the findings, our results raise a valid proposition that purchasing activities and strategic involvement adopted by different culture groups have potentially different impacts on manufacturing competitiveness, especially with regards to cost performance. Our findings in Table 5 suggest that Long-term orientation is a more plausible indicator than geographical location to define country groups and predict the effects of purchasing activities and strategic involvement.

In summary, the SEM results suggest that the relationships among purchasing activities, strategic involvement, and manufacturing competitiveness are not always consistent between the two country groups. Therefore, H3 is supported. Purchasing activity and strategic involvement in the Asia group do not seem to contribute to manufacturing competitiveness in the same manner as is seen in the Western Europe/USA group. In order to gain a deeper understanding of the emphasis and efficacy of particular purchasing activities, we decided to perform further analyses at the individual purchasing activities level.

\subsection{Regression analysis: Contribution of purchasing activities and strategic involvement}


Table 6 displays the descriptive statistics for purchasing activities, strategic involvement, and competitive goal performance. In general, with a few exceptions, countries in Asia receive higher ratings for their efforts in implementing purchasing activities and purchasing strategic involvement. Meanwhile, no statistically significant difference between Asia and Western Europe/USA is found regarding the four aspects of competitiveness.

\section{<Insert Table 6 here>}

Four regression analyses were performed next to examine the effects of individual purchasing activities and strategic involvement on four competitiveness goals. The results of the regression analyses reveal that many purchasing activities contribute to firm performance, but not all activities in both groups similarly or significantly contribute to all four competitiveness goals (see Table 7). More importantly, the contribution of individual purchasing activities and strategic involvement varies between Asia and Western Europe/USA. While strategic involvement influences cost performance in the Asian group, this factor appears to be more influential in Group \#2 on quality, delivery and flexibility performance. For the Asia group, only five out of ten purchasing activities contribute to competitiveness. In contrast, for the Western Europe/USA group, eight out of ten activities have significant effects on manufacturing competitiveness. Only four particular activities (reverse auction, cross-functional team, supply base rationalization, and formal supplier development) are beneficial to both groups. Each country group has a different bundle of purchasing activities that it could implement to enhance performance. Overall, the results in Tables 6 and 7 indicate that the emphasis and efficacy of purchasing activities and strategic involvement between these two groups are substantially different, thus supporting H3a and $\mathrm{H} 3 \mathrm{~b}$ at the item level.

\section{Discussion}

\section{<Insert Table 7 here $>$}

\subsection{Culture and efficacy of purchasing activities and strategic involvement}


Since most purchasing and supply chain management theories were developed based on western culture and data, it is important to verify whether those theories are universal (Pagell et al., 2005; Hofstede, 2007). Our statistical findings suggest that there are differences between the two country groups regarding their emphasis and efficacy of purchasing activities and strategic involvement. The SEM results reveal that the proposed purchasing model, which is well grounded from the purchasing literature, does not receive the same support from the Asian samples despite being verified by the Western Europe/USA data. Three out of eight causal paths were found to be significantly different between the two country groups (Table 5). Several Operations Management (OM) studies previously cautioned about the application of theories developed in North American and European countries to other parts of the world (Pagell et al., 2005; Zhao et al., 2006). This study validates and reinforces that message.

Another interesting observation from the SEM results is that the strength of path coefficients associated with purchasing activities appears to be consistently weaker in Group \#1 (Table 5a, b). On the other hand, the influences of strategic involvement are consistently stronger in Group \#1. This finding implies that purchasing activities and strategic involvement in Asian countries do not have the profound contribution to manufacturing competitiveness as is seen in Group \#2. In other words, Asian firms, with a relatively high long-term orientation, perceive themselves as being more intensively engaged in purchasing activities, but they are not as effective as their Western Europe/USA counterparts regarding the implementation (Tables 6 and 7). Ruamshook et al. (2007) also observed that European countries and the USA have better supply chain management than some of their counterparts in Asia. Clearly, the question appealing to managers is why differences occur, and there may be several possible explanations for differential effectiveness of purchasing activities between the two country groups. For instance, it is likely that the plants in the USA and Western 
Europe have more advanced IT or more expertise to perform some of those purchasing activities (Carr et al., 2000).

It is also possible to attribute the differential effectiveness to the use of Hofstede's culture scale. According to another renowned national culture research project, the GLOBE (Global Leadership and Organizational Behavior Effectiveness) study, cultural dimensions should be assessed from two perspectives, "as is" and "should be" (House et al. 2002). The first perspective indicates where managers believe their country currently is and the latter represent where they believe their country ideally should be. Therefore, it is likely that Hofstede's LTO score captures the "should be" aspect but not the "as is." Based on the GLOBE project, the countries in Group \#1 (Asia) generally have higher "should be" scores than those in Group \#2 (Western Europe/USA), a finding consistent with the information from Hofstede's LTO scores. Meanwhile, Group \#1 has lower “as is” scores than Group \#2. Specifically, the average "as is" score for Group \#1 is 3.89, as opposed to 4.15 for Group \#2. That means, in practice, that the countries in Group \#2 are actually managing their purchasing function more in tune with the long-term perspective (as is), while Group \#1 may desire to be more that way (should be) but fail to. In other words, the mere fact that an Asian firm claims to engage in purchasing activities does not mean that those purchasing activities will be well implemented or deliver competitive advantage. It is beyond the scope of this study to investigate and compare Hofstede's and GLOBE's culture scales, but our findings definitely suggest an interesting future research topic.

\subsection{Culture and engagement of purchasing activities and strategic involvement}

In addition to different path coefficients found from the SEM models, our results reveal that sample plants from Asia perceive that their engagement in purchasing activities and strategic involvement was more intensive and more aligned with competitive strategy (Table 6). As discussed earlier in the literature review (Cavinato et al., 2006; Tucker, 2008), at least three 
purchasing activities have particular long-term implications on manufacturing operations and are likely to be emphasized by countries with high LTO scores. Those three particular activities and the associated LTO scores for both groups are "Formal strategic sourcing process" (4.70 vs. 3.59), "Supply base rationalization" (4.53 vs. 3.60), and "Formal supplier development program" (4.25 vs. 2.78). We decided to examine how much of the difference between the two groups of countries can be accounted for by the cultural dimension Longterm orientation. To do so, we used hierarchical regression with industry and employment entered as controls in the first step and LTO scores entered in the second step. Hierarchical regression was chosen since it provides a clear picture of additional explanatory power created by adding elements of culture to a base model.

Table 8 summarizes the results of hierarchical regression for the three selected purchasing activities: "Formal strategic sourcing process", "Supply base rationalization", and "Formal supplier development program”. For all analyses, we consistently obtain increased adjusted R-squared values after adding the cultural dimension LTO to the control model consisting of only plant size and industry. For "Formal supplier development", the adjusted $\mathrm{R}^{2}$ is .046 with size and industry included in the model, and the addition of LTO score increasing the figure to .201 , or an increase of .155. For the other two activities, the adjusted $\mathrm{R}^{2}$ increases from .029 and .023 to .095 and .087 , respectively. It appears that LTO offers significant explanatory power to the choice and engagement of purchasing activities. Again, these three particular purchasing activities are examined since there is support in the literature for their connection to long-term orientation. Future research should review and verify the effects of culture on other activities.

\section{<Insert Table 8 here $>$}

In summary, our findings from both SEM (Table 5) and regression analysis (Table 7 and Table 8) offer strong support for our research proposition that national culture could affect purchasing activities. National differences or national culture are often treated as control 
variables in OM literature (e.g. Pagell et al., 2005). We are working under the belief that while controlling for culture is better than ignoring it, doing so may still conceal important differences across cultures. Results based on using culture as a control variable may give a false sense of the universality of a theory and/or result. Our findings indicate the significant explanatory power of national culture, validating the need for using national culture to study national differences regarding purchasing and supply chain management decisions.

\section{Conclusions}

Having an understanding of the international cultures involved in purchasing activities is vital to successful operations, but many purchasing managers do not have the necessary understanding of national differences (Belyea, 2008; Riedel and Mueller, 2009). In the past, OM literature often treated national culture as a control variable (e.g. Pagell et al., 2005), ignoring the possibility of using culture as a variable to explain and predict differences in purchasing activities across nations. Responding to the call for better understanding of national differences, this study aims at addressing the research question: Do purchasing theories built on samples from mainly Western companies apply in other cultural contexts? Based on the data collected from ten countries or two distinct cultural groups, we tested a purchasing model that is well-grounded in the literature. Our results suggest that the intensity and efficacy of purchasing activities and strategic involvement vary between the two country groups, Asia and Western Europe/USA. The Western Europe/USA samples adequately fit the purchasing model in Figure 1, but the Asian samples do not. At the item level, we find a common set of purchasing activities contributing to manufacturing competitiveness regardless of national differences. Yet we also find substantial evidence of culturally specific selections of activities. Manufacturing competitiveness is achieved by implementing different bundles of purchasing activities adopted by manufacturing plants from different cultures. In short, the findings suggest that national differences matter in implementing purchasing 
activities. Previously built purchasing theories and models may not be universal and more studies must be done to examine their applicability. While globalization becomes more widespread, the differences between national cultures must be part of research and theory development regarding supply chains.

This study represents a first attempt at using national culture to explain differences in purchasing activities and strategic involvement. To successfully manage an international supply chain, it takes more than knowing that purchasing activities are implemented differently in different countries. While our results clearly suggest the influence of a particular cultural dimension, Long-term orientation, companies must realize what makes purchasing management different in various countries. Specifically, future studies should continue to investigate what dimensions of national culture influence operations decisions and to what extent as well as how that influence occurs. In particular, OM research needs to move beyond macro-level theory that focuses on whether culture matters to the more microlevel question focusing on how culture matters (Pagell et al., 2005). Such an understanding will better prepare multi-national companies to more effectively manage the global supply chain.

This study adopted Hofstede's culture scale to examine the effects of national culture on purchasing activities and decisions. We were able to connect long-term orientation scores with the emphasis firms in different countries place on their purchasing activities and strategic involvement. Nonetheless, Hofstede's culture score failed to predict the efficacy of purchasing activities and strategic involvement. Future OM research should examine and compare alternative culture scales (e.g., the GLOBE study) regarding their pros and cons for assessing various aspects of purchasing and supply chain decisions. A reliable scale that could accurately capture various cultural dimensions would be beneficial to multinational firms. Other cultural dimensions such as uncertainty avoidance and assertiveness should also 
be investigated for their relevance to purchasing activities between countries. Finally, we examined a list of purchasing activities that were carefully selected based on the literature and suggestions from renowned scholars who are familiar with the industry practice. It is still possible that some important purchasing activities may have been overlooked. 


\section{APPENDIX A}

(1) Manufacturing Competitiveness (MC): For each of the items listed below, how does your plant's performance compare with your major competitors? $(1=$ Far worse, $7=$ Far better)

a. Cost: direct manufacturing costs, total product costs, raw material costs

b. Quality: product features, product performance, perceived overall product quality

c. Delivery: order fulfillment speed, delivery as promised, delivery flexibility

d. Flexibility: flexibility to change output volume, flexibility to change product mix, manufacturing throughput time

(2) Purchasing Strategic Involvement (SI) (1= Not at all, 7 = A great degree)

a. To what degree does your procurement organization influence (have direct input to) the overall long-term strategic plan?

b. To what degree does top management support the strategic importance of purchasing by providing adequate financial resources?

(3) Purchasing Activity (PA): To what extent are the following activities implemented to contribute to the organization's competitive goals? $(1=$ Not at all, $7=$ A great extent $)$ 


\section{REFERENCES}

Atkinson, W. (2006), "Centralizing delivers new procurement value", Purchasing, Vol. 135 No. 10 , pp. 25-26.

Barnes, D. (2008), Operations Management: An International Perspective. Cengage Learning EMEA, Australia.

Belyea, N. (2008), "New to purchasing? Here are some tips from a veteran", Purchasing, Vol. 128 No. 1, pp. 173.

Carr, A.S., Leong, K.G. and Sheu, C. (2000), "A study of purchasing policies in Taiwan", International Journal of Operations \& Production Management, Vol. 20 No. 12, pp. 1427-1446.

Carr, A.S. and Pearson, J.N. (1999), "Strategically Managed Buyer-Supplier Relationships and Performance Outcomes", Journal of Operations Management, Vol. 17 No. 5, pp. 497-519.

Carter, P., Carter, R., Monczka, R., Slaight, T. and Swan, A. (2000), "The Future of Purchasing and Supply: A Ten-Year Forecast", Journal of Supply Chain Management, Vol. 36 No. 1, pp. 14-26.

Cavinato, J.L., Flynn, A.E. and Kauffman, R.G. (2006), The Supply Management Handbook, McGraw-Hill, New York, NY.

Chen, I., Paulraja, A. and Lado, A. (2004), "Strategic purchasing, supply management and firm performance", Journal of Operations Management, Vol. 22, pp. 505-523.

Das, A. and Narasimhan, R. (2000), "Purchasing competence and its relationship with manufacturing performance", Journal of Supply Chain Management, Vol. 36 No. 2, pp. $17-28$.

Dyer, J.H., Cho, D.S. and Chu, W. (1998), "Strategic supplier segmentation: The next best practice in supply chain management", California Management Review, Vol. 40 No. 2, pp. 57-77.

Ellram, L. and Edis, O. (1996), “A case study of successful partnering implementation”, International Journal of Purchasing and Materials Management, Vol. 32 No. 4, pp. 20 28.

Ellram, L. M., Siferd, S.P., Zsidisin, G. and Stanly, M. (2002), "The impact of purchasing and supply chain management activities on corporate success", Journal of Supply Chain Management, Vol. 38 No. 1, 2002, pp. 4-17.

Essig, M. and Arnold, U. (2001), "Electronic procurement in supply chain management: An information economics-based analysis of electronic markets", Journal of Supply Chain Management, Vol. 37 No. 4, pp. 43-49.

Flynn, B.B. and Saladin, B. (2006), "Relevance of Baldrige constructs in an international context: A study of national culture", Journal of Operations Management, Vol. 24 No. 5, pp. 583-603.

Fornell, C. and Larcker, D.F. (1981), "Evaluating structural equation models with unobservable variables and measurement error", Journal of Marketing Research, Vol. 18 No. 1, pp. 39-50.

Gray, C.F. and Larson, E.W. (2006), Project Management: The Managerial Process, McGraw-Hill, New York, NY.

Hair, J.F., Anderson, R.E., Tatham, R.L. and Black, W.C. (1998), Multivariate Data Analysis, Prentice Hall, Upper Saddle River, NJ. 
Hendrick, T., Carter, C. and Siferd, S. (1996), "Purchasing's involvement in time-based strategies", International Journal of Purchasing and Materials Management, Vol. 32 No. 3, pp. 2-10.

Hofstede, G. (1980), Culture's Consequences: International Differences in Work-Related Values, Sage Publications, Beverly Hills, CA.

Hofstede, G. (2007), “Asian management in the $21^{\text {st }}$ century”, Asian Pacific Journal of Management, Vol. 24, pp. 411-420

Hofstede, G., Van Deusen, C., Mueller, B. and Mueller, T. (2002), "What goals do business leaders pursue? A study in fifteen countries", Journal of International Business Studies, Vol. 33 No. 4, pp. 785-803.

House, R., Javidan, M., Hanges, P. and Dorfman, P. (2002), "Understanding cultures and implicit leadership theories across the globe: An introduction to project GLOBE", Journal of World Business, Vol. 37 No. 1, pp.3-10.

$\mathrm{Hu}, \mathrm{L}-\mathrm{T}$. and Bentler, P.M. (1998), "Fit indices in covariance structure modeling: Sensitivity to underparameterized model misspecification”, Psychological Methods, Vol. 3 No. 4, pp. 424-453.

Johnson, P.F., Leenders, M. and Fearson, H. (1998), "The influence of organizational factors on purchasing activities", International Journal of Purchasing and Materials Management, Vol. 34 No. 3, pp. 10-19.

Kannan, V. and Tan, K. (2002), "Supplier selection and assessment: Their impact on business performance", Journal of Supply Chain Management, Vol. 38 No. 4, pp. 11-21.

Ketokivi, M.A. and Schroeder, R.G. (2004), "Perceptual measures of performance: Fact or fiction?” Journal of Operations Management, Vol. 22 No. 3, pp. 247-264.

Kinner, G. and Marci, P. (2005), "E-procurement-strengthening the indirect supply chain through technology globalization", Intel Technology Journal, Vol. 9 No. 3, pp. 203-210.

Krause, D. R., Scannell, T.V. and Calantone, R.J. (2000), “A structural analysis of the effectiveness of buying firms' strategies to improve supplier performance". Decision Sciences. Vol 31 No. 1, 33-55.

Krause, D.R., Pagell, M. and Curkovic, S. (2001), "Towards a measure of competitive priorities for purchasing”, Journal of Operations Management, Vol. 19 No. 4, pp. 497 512.

Kristal, M. Pagell, M., Yang, C. and Sheu, C. (2011), "Are supply chain management theories culturally constrained? An empirical assessment," Operations Management Research. Vol. 4 No. 1, pp. 61-73.

Kull, T. and Wacker, J.G. (2010), "Quality management effectiveness in Asia: The influence of culture", Journal of Operations Management, Vol. 28 No. 3, pp. 223-239.

Lawson, B., Cousins, P., Handfield, R. and Petersen, K. (2009), "Strategic purchasing, supply management practices and buyer performance improvement: An empirical study of UK manufacturing organisations", International Journal of Production Research, Vol. 47 No. 10, pp. 2649-2667.

McIvor, R. and McHugh, M. (2000), "Partnership sourcing: An organization change management perspective", Journal of Supply Chain Management, Vol. 36 No. 3, pp. 1220.

Meyer, K.E. (2007), "Asian contexts and the search for general theory in management research: A rejoinder”, Asian Pacific Journal of Management, Vol. 24, pp. 527-534. 
Monczka, R.M., Handfield, R.B., Giunipero, L.C. and Patterson, J.L. (2009), Purchasing \& Supply Chain Management, South-Western, Mason, $\mathrm{OH}$.

Narasimhan, R. and Das, J. (2001), "The impact of purchasing integration and practices on manufacturing performance", Journal of Operations Management, Vol. 19, pp. 593-609.

Niehoff, B., Yang, C., Hsu, L. and Sheu, C. (2011), "A Comparison of European, US, and Asian manufacturing plants on the use of green practices", Irish Journal of Management, Vol. 30 No. 2, pp. 1-16.

Nunnally, J.C. (1978), Psychometric Theory, McGraw-Hill, New York, NJ.

O'Leary-Kelly, S.W. and Vokurka, R.J. (1998), "The empirical assessment of construct validity”, Journal of Operations Management, Vol. 16 No. 4, pp. 387-405.

Pagell, M., Katz, J.P. and Sheu, C. (2005), "The importance of national culture in operations management research", International Journal of Operations and Production Management, Vol. 25 No. 4, pp. 371-394.

Pearson, J., Carter, J. and Peng, L. (1998), “Alliances, logistics barriers, and strategic actions in the People's Republic of China", International Journal of Purchasing and Materials Management, Vol. 34 No. 3, pp. 27-36.

Petersen, K.J., Handfield, R.B. and Ragatz, G.L. (2005), "Supplier integration into new product development: Coordinating product, process and supply chain design", Journal of Operations Management, Vol. 23 No. 3/4, pp. 371-388.

Prahinski, C. and Benton, W. (2004), "Supplier evaluations: Communication strategies to improve supplier performance", Journal of Operations Management, Vol. 22, pp. 39-62.

Primo, M. and Amundson, S. (2002), "An exploratory study of the effects of supplier relationships on new product development outcomes", Journal of Operations Management, Vol. 20, pp. 33-52

Qing, Y., Zhao, X. and Sheu, C. (2011), "Competitive strategy, supply chain strategy and business performance: moderating effects of environmental uncertainty", Decision Sciences Journal. Vol. 42 No. 2, pp. 371-389.

Quintens, L., Pauwels, P. and Matthyssens, P. (2006), "Global purchasing strategy: Conceptualization and measurement", Industrial Marketing Management, Vol. 32, pp. 881-891.

Rhea, S. (2007), "Reverse physiology”, Modern Healthcare, Vol. 37 No. 38, pp. 40-42.

Riedel, R. and Mueller, E. (2009), "Production management and supply chain management in a global context", International Journal of Manufacturing Technology and Management, Vol. 16 No. 3, pp. 300-317.

Rozemeijer, F.A., Weele, A.V. and Weggeman, M. (2003), "Creating corporate advantage through purchasing: Toward a contingency model", Journal of Supply Chain Management, Vol. 39 No. 1, pp. 4-14.

Ruamsook, K., Russell, D. and Thomchick, E. (2007), "Sourcing from low cost countries: A comparative analysis of supplier performance", Journal of Supply Chain Management, Vol. 42, No. 1, pp. 16-30.

Sarin, S. and McDermott, C. (2003), "The effect of team leader characteristics on learning, knowledge application, and performance of cross-functional new product development teams", Decision Sciences Journal, Vol. 34 No. 4, pp. 707-738.

Shrader, R., Shrader, J. and Eller, E. (2004), "Strategic implications of reverse auctions", Journal of Business-to-Business Marketing, Vol. 11 No. 1/2, pp. 61-80. 
Sislain, E. and Satir, A. (2000), "Strategic sourcing: A framework and a case study", Journal of Supply Chain Management, Vol. 36 No. 3, pp. 4-11.

Talluri, S. and Narasimhan, R. (2004), "A methodology for strategic sourcing", European Journal of Operational Research, Vol. 154 No. 1, pp. 236-250.

Talluri, S. and Sarkis, J. (2002), "A model for performance monitoring of suppliers", International Journal of Production Research, Vol. 40 No. 16, pp. 4257-4269.

Tan, K. (2002), "Supply chain management: Practices, concerns, and performance issues", Journal of Supply Chain Management, Vol. 38 No. 1, pp. 42-53.

Trent, R. (2004), "The use of organizational design features in purchasing and supply management", Journal of Supply Chain Management, Vol. 40 No. 3, pp. 4-18.

Tucker, M.F. (2008), “The rise of tech valley”, Economic Development Journal, pp. 34-40.

Vonderembse, M. and Tracey, M. (1999), "The impact of supplier selection criteria and supplier involvement on manufacturing performance", Journal of Supply Chain Management, Vol. 35 No. 3, pp. 33-39.

Wacker, J.G. and Spargue, L. (1998), "Forecasting accuracy: Comparing the relative effectiveness of practices between seven developed countries", Journal of Operations Management, Vol. 16 No. 2/3, pp. 271-290.

Whybark, C., Wacker, J. and Sheu, C. (2009), “The evolution of an international academic manufacturing survey", Decision Line, May, pp. 17-19.

Womack, J. P. and Jones, D. T. (2003), Lean Thinking, 2nd ed., Free Press, New Yor, NY.

Yang, C.L., Lin, S.P., Chan, Y. and Sheu, C. (2010), "Mediated effect of environmental management on manufacturing competitiveness: An empirical study", International Journal of Production Economics. Vol. 123 No. 1, pp. 210-220.

Zhao, X., Sum, C.C., Qi, Y., Zhang, H. and Lee, T.S. (2006), “A taxonomy of manufacturing strategies in China”, Journal of Operations Management, Vol. 24 No. 3, pp. 621-636. 
Table 1. Hofstede's cultural dimension indices

\begin{tabular}{|l|c|c|c|c|}
\hline \multicolumn{1}{|c|}{ Cultural Dimension } & Asia & Europe & USA & $\begin{array}{c}\text { World } \\
\text { Average }\end{array}$ \\
\hline $\begin{array}{l}\text { Power Distance: the extent to which the less } \\
\text { powerful members of organizations and institutions } \\
\text { (like the family) accept and expect that power is } \\
\text { distributed unequally. }\end{array}$ & 60 & 40 & 38 & 52 \\
\hline $\begin{array}{l}\text { Individualism: the relationship between the } \\
\text { individual and the collective }\end{array}$ & 20 & 56 & 90 & 40 \\
\hline $\begin{array}{l}\text { Masculinity: the extent to which gender affects the } \\
\text { division of labor }\end{array}$ & 52 & 52 & 60 & 48 \\
\hline $\begin{array}{l}\text { Uncertainty Avoidance: the extent to which } \\
\text { countries deem the pursuit of certainty important }\end{array}$ & 60 & 70 & 42 & 61 \\
\hline $\begin{array}{l}\text { Long Term Orientation (Confucianism): the } \\
\text { extent to which one has a long- or short-term } \\
\text { orientation, especially toward respect for tradition, } \\
\text { fulfilling social obligations, and protecting one's } \\
\text { face. }\end{array}$ & 95 & 25 & 25 & 41 \\
\hline
\end{tabular}

Source: www.geert-hofstede.com

Table 2. Long-term orientation (LTO) score and sample size

\begin{tabular}{|c|c|c|}
\hline Group \& Country & LTO score & Sample size (n) \\
\hline Group \#1: Asia & Avg $=93.33$ & Total $=210$ \\
\hline - China & 118 & 57 \\
\hline - Korea & 75 & 103 \\
\hline - Taiwan & 87 & 50 \\
\hline Group \#2: W. Europe/USA & Avg $=33.29$ & Total $=301$ \\
\hline - Australia & 31 & 30 \\
\hline - Austria & 31 & 16 \\
\hline - Germany & 31 & 58 \\
\hline - Italy & 34 & 51 \\
\hline - Sweden & 33 & 31 \\
\hline - Switzerland & 44 & 31 \\
\hline - USA & 29 & 84 \\
\hline
\end{tabular}

Total number of samples $=511$ 
Table 3. Sample demographics

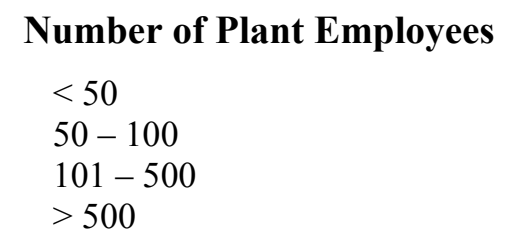

\section{Industry}

Electric \& Electronic equipment (SIC 35 \& 36)

Primary \& fabricated metal (SIC $34 \& 33$ )

Plastic (SIC 30)

Others (e.g., Textile, food, chemicals, etc.)

$\begin{array}{lcl}\begin{array}{l}\text { Overall } \\ (\mathbf{n = 5 1 1})\end{array} & \begin{array}{l}\text { Asia } \\ (\mathbf{n = 2 1 0})\end{array} & \begin{array}{l}\text { W.Europe/USA } \\ (\mathbf{n}=\mathbf{3 0 1})\end{array} \\ 15.8 \% & 9.3 \% & 17.3 \% \\ 23.2 & 25.7 & 22.4 \\ 40.9 & 40.4 & 42.1 \\ 20.1 & 24.6 & 18.2 \\ & & \\ 100.0 \% & 100.0 \% & 100.0 \% \\ & & \\ & & \\ 24.5 \% & 59.6 \% & 16.5 \% \\ 27.7 & 10.3 & 28.5 \\ 12.4 & 8.3 & 15.9 \\ 35.4 & 21.8 & 39.1 \\ 100.0 \% & 100.0 \% & 100.0 \%\end{array}$


Table 4. Factor loading and construct reliability analysis $(\mathrm{N}=511)$

Fit indices for the overall CFA model (encompassing all factors): $\chi^{2}=529.916, \mathrm{df}=237, \chi^{2} / \mathrm{df}=$ $2.236, \mathrm{IFI}=.944, \mathrm{NNFI}=.904, \mathrm{CFI}=.944, \mathrm{RMSEA}=.049$.

\begin{tabular}{|c|c|}
\hline Factor/Items (Cronbach $\alpha)$ & $\begin{array}{c}\text { Factor } \\
\text { loading }\end{array}$ \\
\hline \multicolumn{2}{|l|}{ 1. Purchasing Activity (PA): Alpha $=0.893 ; C R=.821$} \\
\hline PA1. Buyer sponsored supplier conferences & .642 \\
\hline PA2. Formal strategic sourcing process & .667 \\
\hline PA3. Reverse auctions & .685 \\
\hline PA4. Supplier representatives in plant* & NA \\
\hline PA5. Strategic alliances/partnerships* & NA \\
\hline PA6. Commercial procurement software & .706 \\
\hline PA7. Cross-functional commodity teams & .715 \\
\hline PA8. Early supplier involvement in design & .646 \\
\hline PA9. Non-direct materials & .696 \\
\hline PA10. Supply base rationalization & .674 \\
\hline PA11. Purchased items classified as strategic or tactical & .643 \\
\hline PA12. Formal supplier development program & .746 \\
\hline \multicolumn{2}{|l|}{ 2. Strategic Involvement (SI) } \\
\hline SI1. Input to overall long-term strategic plan & .829 \\
\hline SI2. Top management support & .781 \\
\hline \multicolumn{2}{|l|}{ 3. Manufacturing Competitiveness (MC) } \\
\hline \multicolumn{2}{|l|}{ Cost performance: Alpha $=0.827 ; C R=.863$} \\
\hline MC1. Manufacturing costs & .872 \\
\hline MC2. Product costs & .899 \\
\hline MC3. Raw material costs & .748 \\
\hline \multicolumn{2}{|l|}{ Quality performance: Alpha $=0.868 ; C R=.865$} \\
\hline MC4. Product features & .870 \\
\hline MC5. Product performance & .901 \\
\hline MC6. Product quality & .808 \\
\hline \multicolumn{2}{|l|}{ Delivery performance: Alpha $=0.751 ; C R=.738$} \\
\hline MC7. Order fulfillment speed & .825 \\
\hline MC8. Delivery speed & .669 \\
\hline MC9. Delivery flexibility & .663 \\
\hline \multicolumn{2}{|l|}{ Flexibility performance: Alpha $=0.768 ; C R=.761$} \\
\hline MC10. Flexibility to change output volume & .832 \\
\hline MC11. Flexibility to change product mix & .790 \\
\hline
\end{tabular}

*: Items are deleted due to the low factor loadings or high cross-loadings 
Table 5. SEM results

(a) Multi-group SEM: Two groups

\begin{tabular}{|c|c|c|c|c|}
\hline \multirow[b]{2}{*}{$\begin{array}{c}\text { Structural } \\
\text { path }\end{array}$} & \multicolumn{3}{|c|}{ Path coefficients (Standardized) } & \multirow[b]{2}{*}{$\Delta \chi^{2}(d f=1)$} \\
\hline & All sample & $\begin{array}{l}\text { Group \#1: Asia } \\
\quad(\mathrm{n}=210)\end{array}$ & $\begin{array}{c}\text { Group \#2: } \\
\text { W. Europe/USA } \\
(\mathrm{n}=301)\end{array}$ & \\
\hline $\mathrm{PA} \rightarrow$ Cost & $1.77 *$ & 1.04 & $1.56^{* *}$ & $42.52 * *$ \\
\hline PA $\rightarrow$ Quality & $2.04 *$ & 1.62 & $1.72 * *$ & $21.62 *$ \\
\hline PA $\rightarrow$ Delivery & $4.30^{*}$ & $3.49 * *$ & $3.54 * *$ & 0.36 \\
\hline PA $\rightarrow$ Flexibility & $4.09 *$ & $3.36^{* *}$ & $3.42 * *$ & 0.53 \\
\hline $\mathrm{SI} \rightarrow \mathrm{Cost}$ & $2.04 *$ & $1.64 * *$ & $1.09 *$ & $50.56 * *$ \\
\hline SI $\rightarrow$ Quality & $2.24 *$ & $1.84 *$ & $1.72 *$ & 4.71 \\
\hline SI $\rightarrow$ Delivery & $4.47 *$ & $3.69 * *$ & $3.65 * *$ & -0.24 \\
\hline SI $\rightarrow$ Flexibility & $4.43 *$ & $3.67 * *$ & $3.62 * *$ & 0.33 \\
\hline
\end{tabular}

$\chi^{2}=528.58 ;$ RMSEA $=0.050 ; \mathrm{NFI}=0.94 ; \mathrm{CFI}=0.96 ; \mathrm{RMR}=0.050 ; \mathrm{GFI}=0.92$

(b) Multi-group SEM: Three Groups

\begin{tabular}{|c|c|c|c|c|c|}
\hline \multirow[b]{2}{*}{$\begin{array}{l}\text { Structural } \\
\text { path }\end{array}$} & \multicolumn{4}{|c|}{ Path coefficients (Standardized) } & \multirow[b]{2}{*}{$\Delta \chi^{2}(d f=2)$} \\
\hline & All sample & $\begin{array}{c}\text { Group \#1: } \\
\text { Asia } \\
(\mathrm{n}=210)\end{array}$ & $\begin{array}{c}\text { Group \#2: } \\
\text { W. Europe } \\
(\mathrm{n}=217)\end{array}$ & $\begin{array}{c}\text { Group \#3: } \\
\text { USA } \\
(\mathrm{n}=84)\end{array}$ & \\
\hline $\mathrm{PA} \rightarrow$ Cost & $1.77^{*}$ & 1.70 & $2.18^{*}$ & $2.19^{*}$ & $37.66^{* *}$ \\
\hline PA $\rightarrow$ Quality & $2.04 *$ & 1.38 & $2.41 *$ & $2.64 *$ & $23.51^{*}$ \\
\hline PA $\rightarrow$ Delivery & $4.30^{*}$ & $5.06^{*}$ & $5.13^{*}$ & $5.09 *$ & 0.26 \\
\hline PA $\rightarrow$ Flexibility & $4.09 *$ & $4.88^{*}$ & $4.96^{*}$ & $4.91 *$ & 0.83 \\
\hline SI $\rightarrow$ Cost & $2.04 *$ & $2.23 * *$ & $1.51^{*}$ & $1.50^{*}$ & $44.02 * *$ \\
\hline SI $\rightarrow$ Quality & $2.24 *$ & $2.52 *$ & $2.49 *$ & $2.24 *$ & 4.71 \\
\hline SI $\rightarrow$ Delivery & $4.47^{*}$ & $5.08^{*}$ & $5.01 *$ & $5.10^{*}$ & -0.06 \\
\hline SI $\rightarrow$ Flexibility & $4.43 *$ & $5.09 *$ & $5.01 *$ & $5.09 *$ & 0.9 \\
\hline
\end{tabular}

$\chi^{2}=528.58 ;$ RMSEA $=0.050 ; \mathrm{NFI}=0.94 ; \mathrm{CFI}=0.96 ; \mathrm{RMR}=0.050 ; \mathrm{GFI}=0.92$

$* \mathrm{p}<0.05 ; * * \mathrm{p}<0.01$ 
Table 6. Mean score: Purchasing activities, strategic involvement and competitiveness

\begin{tabular}{|l|c|c|c|}
\hline \multicolumn{1}{|c|}{ Item } & $\begin{array}{c}\text { Group \#1 } \\
(\text { Asia }) \\
(\mathrm{n}=210)\end{array}$ & $\begin{array}{c}\text { Group \#2 (W. } \\
\text { Europe/USA) } \\
(\mathrm{n}=301)\end{array}$ & $\begin{array}{c}\text { Group mean } \\
\text { difference }\end{array}$ \\
\hline$\bullet$ Purchasing strategic involvement & 4.80 & 4.63 & $*$ \\
\hline$\bullet$ Buyer sponsored supplier conferences & 4.08 & 4.04 & -- \\
\hline$\bullet$ Formal strategic sourcing process & 4.70 & 3.59 & $* *$ \\
\hline$\bullet$ Reverse auctions & 3.34 & 3.97 & $* *$ \\
\hline$\bullet$ Commercial procurement software & 3.83 & 2.39 & $* *$ \\
\hline$\bullet$ Cross-functional commodity teams & 3.99 & 2.76 & $* *$ \\
\hline$\bullet$ Early supplier involvement in design & 4.47 & 4.67 & $* *$ \\
\hline$\bullet$ Non-direct materials & 4.16 & 3.04 & $* *$ \\
\hline$\bullet$ Supply base rationalization & 4.53 & 3.60 & $* *$ \\
\hline$\bullet$ Items classified as strategic or tactical & 3.89 & 3.95 & -- \\
\hline$\bullet$ Formal supplier development program & 4.25 & 2.78 & $* *$ \\
\hline$\bullet$ Cost & 4.66 & 4.31 & -- \\
\hline$\bullet$ Quality & 5.46 & 5.51 & -- \\
\hline$\bullet$ Delivery & 5.07 & 5.21 & -- \\
\hline$\bullet$ Flexibility & 5.11 & 4.96 & -- \\
\hline
\end{tabular}

$* \mathrm{p}<0.05 ; * * \mathrm{p}<0.01$ 
Table 7. Individual purchasing activities, strategic involvement, and competitiveness

\begin{tabular}{|c|c|c|c|c|c|c|c|c|}
\hline \multirow{2}{*}{ Items } & \multicolumn{4}{|c|}{ Group \#1 $(\mathrm{n}=210)$} & \multicolumn{4}{|c|}{ Group \#2 $(n=301)$} \\
\hline & Cost & Quality & Delivery & Flex. & Cost & Quality & Delivery & Flex. \\
\hline $\begin{array}{l}\text { PA1. Buyer sponsored } \\
\text { supplier conferences }\end{array}$ & & & & & & $(+)^{* *}$ & & \\
\hline $\begin{array}{l}\text { PA2. Formal strategic } \\
\text { sourcing process }\end{array}$ & & & $(+)^{* *}$ & $(+)^{* *}$ & & & & \\
\hline PA3. Reverse auctions & $(+)^{* *}$ & & & & $(+)^{* *}$ & & & \\
\hline $\begin{array}{l}\text { PA4. Commercial } \\
\text { procurement software }\end{array}$ & & & & & & & & \\
\hline $\begin{array}{l}\text { PA5. Cross-functional } \\
\text { commodity teams }\end{array}$ & $(+)^{* *}$ & & & & & $(+)^{* *}$ & & \\
\hline $\begin{array}{l}\text { PA6. Early supplier } \\
\text { involvement in design }\end{array}$ & & & & & & $(+)^{* *}$ & & \\
\hline PA7. Non-direct materials & & & & & & & & $(+)^{* *}$ \\
\hline $\begin{array}{l}\text { PA8. Supply base } \\
\text { rationalization }\end{array}$ & $(+)^{*}$ & & & & $(+)^{*}$ & & & \\
\hline $\begin{array}{l}\text { PA9. Purchased items } \\
\text { classified as strategic or } \\
\text { tactical }\end{array}$ & & & & & & $(+)^{*}$ & & \\
\hline $\begin{array}{l}\text { PA10. Formal supplier } \\
\text { development program }\end{array}$ & & & $(+)^{* *}$ & & & & $(+)^{* *}$ & \\
\hline $\begin{array}{l}\text { Purchasing Strategic } \\
\text { Involvement }\end{array}$ & $(+)^{* *}$ & & & & & $(+)^{* *}$ & $(+)^{* *}$ & $(+)^{* *}$ \\
\hline
\end{tabular}

$* \mathrm{p}<0.05 ; * * \mathrm{p}<0.01$

Table 8. Hierarchical regression: LTO and purchasing activities

\begin{tabular}{|c|l|r|l|r|l|r|}
\hline \multirow{2}{*}{} & \multicolumn{9}{|c|}{ Selected Purchasing Activities } \\
\cline { 2 - 7 } & \multicolumn{2}{|c|}{ Formal strategic sourcing } & \multicolumn{2}{c|}{$\begin{array}{c}\text { Supply base } \\
\text { rationalization }\end{array}$} & \multicolumn{2}{c|}{$\begin{array}{c}\text { Formal supplier } \\
\text { development }\end{array}$} \\
\hline \multirow{3}{*}{ Step } & $\begin{array}{c}\text { Model } \\
\text { variables }\end{array}$ & $\begin{array}{r}t \text {-value (sig.), } \\
\text { Adjusted } \mathrm{R}^{2}\end{array}$ & $\begin{array}{c}\text { Model } \\
\text { variables }\end{array}$ & $\begin{array}{c}t \text {-value (sig.), } \\
\text { Adjusted } \mathrm{R}^{2}\end{array}$ & $\begin{array}{c}\text { Model } \\
\text { variables }\end{array}$ & $\begin{array}{c}t \text {-value (sig.), } \\
\text { Adjusted } \mathrm{R}^{2}\end{array}$ \\
\hline \multirow{2}{*}{1} & Size & $3.638(.000)$ & Size, & $3.415(.001)$ & Size, & $4.738(.000)$ \\
& Industry & $-.168(.064)$ & Industry & $-1.323(.186)$ & Industry & $-1.857(.064)$ \\
& & Adj. $\mathrm{R}^{2}=.029$ & & Adj. $\mathrm{R}^{2}=.023$ & & Adj. $\mathrm{R}^{2}=.046$ \\
\hline \multirow{2}{*}{2} & Size & $2.376(.018)$ & Size, & $2.163(.031)$ & Size, & $2.965(.003)$ \\
& Industry & $-.712(.477)$ & Industry & $-.180(.858)$ & Industry & $-.111(.911)$ \\
& LTO & $6.150(.000)$ & LTO & $6.078(.000)$ & LTO & $9.785(.000)$ \\
& & Adj. $\mathrm{R}^{2}=.095$ & & Adj. $\mathrm{R}^{2}=.087$ & & Adj. $\mathrm{R}^{2}=.201$ \\
\hline
\end{tabular}

Independent variables: Size, industry, LTO 
Figure 1. Theoretical model

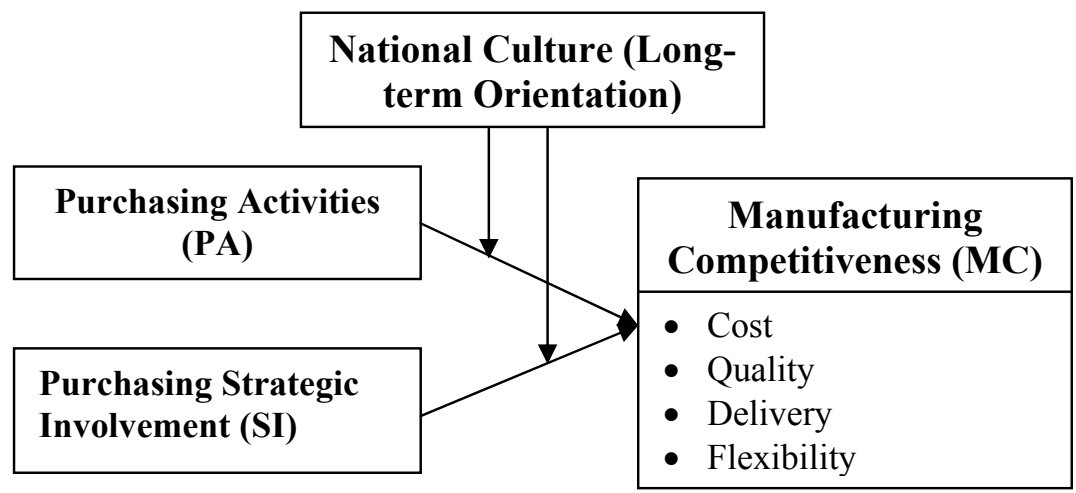

